\title{
A giant prolactinoma with nasopharyngeal extension presenting with nasal blockage and epistaxis
}

\author{
Jaya Prakash Sahoo, ${ }^{1}$ Sadishkumar Kamalanathan, ${ }^{1}$ Pradipta Kumar Parida, ${ }^{2}$ \\ Vivekanandan Pillai ${ }^{1}$
}

'Department of Endocrinology, Jawaharlal Institute of Post Graduate Medical Education \& Research, Puducherry, India 2Department of ENT, Jawaharlal Institute of Postgraduate Medical Education and Research (JPMER), Puducherry, India

\section{Correspondence to} Dr Jaya Prakash Sahoo, jppgi@yahoo.com

Accepted 6 April 2015

\section{(a) CrossMark}

To cite: Sahoo JP Kamalanathan S, Parida PK, et al. BMJ Case Rep Published online: [please include Day Month Year doi:10.1136/bcr-2014208811

\section{DESCRIPTION}

A 35-year-old woman presented to the ear, nose and throat outpatient department with headache and a blocked left-sided nasal canal with epistaxis for 2 years. Medical history revealed secondary amenorrhoea for the past 19 years with regression of secondary sexual characteristics with no galactorrhoea. Physical and ophthalmological examinations were within normal limits. Nasal examination revealed a left-sided choanal mass. As the mass was bleeding on palpation, imaging was advised prior to performing a biopsy. MRI of the head showed a sellar and infra-sellar mass extending into the nasopharynx (figure 1). The patient was then referred to the endocrinologist for further hormonal investigation. Her serum prolactin was very high$7443 \mu \mathrm{g} / \mathrm{L} \quad(\mathrm{N}<20)$. Other pituitary hormones were within normal limits. A final diagnosis of giant prolactinoma was made and the patient was

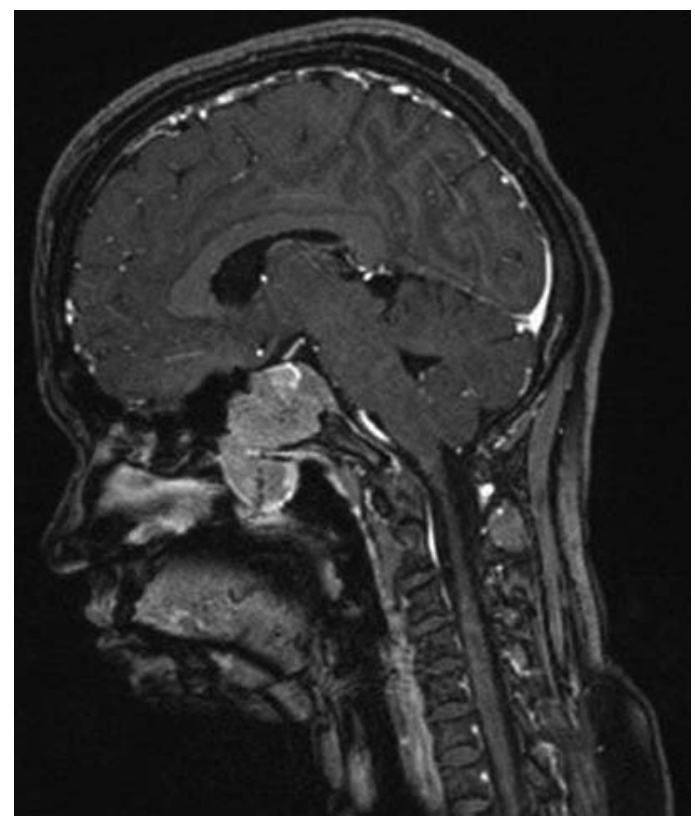

Figure 1 MRI of the head (sagittal T1-weighted postcontrast) showing a sellar-infrasellar mass extending into the nasopharynx. prescribed cabergoline $0.25 \mathrm{mg}$ twice per week with the associated risks explained in advance.

Prolactinomas account for 57\% of pituitary tumours. ${ }^{1}$ Female patients with prolactinoma typically present with menstrual irregularities and galactorrhoea; however, galactorrhoea may be absent in patients with severe hypogonadism, as seen in our present case. ${ }^{2}$ Giant prolactinoma presenting with nasal blockage and epistaxis is rare in the current literature. $^{3}$ Cabergoline (a dopamine receptor agonist) is the first-line treatment for these patients, with endoscopic trans-spheroidal surgery and radiosurgery as secondary alternatives. However, surgery may be considered upfront if the patient presents with visual compromise. The present case highlights the importance of considering pituitary adenoma and in particular giant prolactinoma as part of the differential diagnosis for choanal masses.

\section{Learning points}

- Giant prolactinoma should be considered as a differential diagnosis of epistaxis with nasal blockage.

- Galactorrhoea may not be present in all cases of prolactinoma.

- Secondary amenorrhea can be a pointer to the diagnosis of prolactinoma.

Competing interests None declared.

Patient consent Obtained.

Provenance and peer review Not commissioned; externally peer reviewed.

\section{REFERENCES}

1 Rogers A, Karavitaki N, Wass JA. Diagnosis and management of prolactinomas and non-functioning pituitary adenomas. BMJ 2014;349:g5390

2 Franks S, Murray MA, Jequier AM, et al. Incidence and significance of hyperprolactinaemia in women with amenorrhea. Clin Endocrino (Oxf) 1975:4:597-607.

3 Minniti G, Jaffrain-Rea ML, Santoro A, et al. Giant prolactinomas presenting as skull base tumors. Surg Neurol 2002;57:99-103. 


\section{Images in...}

Copyright 2015 BMJ Publishing Group. All rights reserved. For permission to reuse any of this content visit http://group.bmj.com/group/rights-licensing/permissions.

BMJ Case Report Fellows may re-use this article for personal use and teaching without any further permission.

Become a Fellow of BMJ Case Reports today and you can:

- Submit as many cases as you like

- Enjoy fast sympathetic peer review and rapid publication of accepted articles

- Access all the published articles

- Re-use any of the published material for personal use and teaching without further permission

For information on Institutional Fellowships contact consortiasales@bmjgroup.com

Visit casereports.bmj.com for more articles like this and to become a Fellow 